\title{
Sumatran orangutans and the World War II
}

\author{
Tetsuro Matsuzawa ${ }^{1,2}$
}

Published online: 9 June 2015

(C) Japan Monkey Centre and Springer Japan 2015

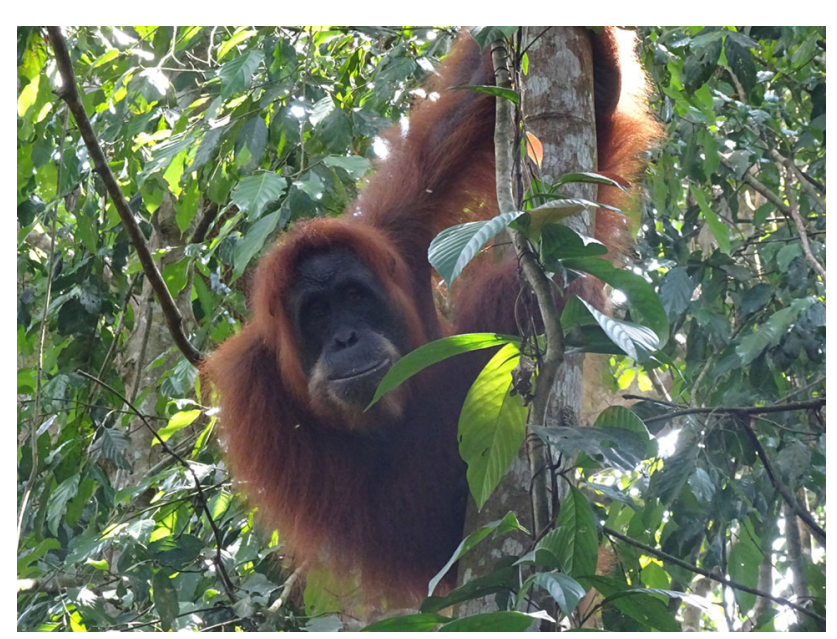

Adult female Sumatran orangutan in Gunung Leuser National Park (photo credit: T. Matsuzawa)

This April and May, I was in Sumatra to carry out a short field survey of wild Sumatran orangutans (Pongo abelii). Setting out from Medan, the fourth largest city in Indonesia, I visited orangutan field sites in the Province of North Sumatra.

As many of you may already know, the word 'orangutan' is made up of two separate words. In the local languages of Malay and Indonesian, "Orang" means "people" or "person". "Hutan" means "forest". So "Orang Hutan" becomes orangutan. Orangutan means 'man of the forest'. Orangutans

Tetsuro Matsuzawa

matsuzawa.tetsuro.8w@kyoto-u.ac.jp

Japan Monkey Centre, Inuyama, Japan

2 Kyoto University, Inuyama, Japan can now be found only on Sumatra and Borneo. These islands are enormous. Sumatra is the world's sixth largest island, with an area $(473,000$ square $\mathrm{km})$ greater than the US state of California that is greater than Japan that is slightly greater than Germany. I have been visiting Bornean orangutans (Pongo pygmaeus morio), in Danum Valley, Sabah, Borneo, since 1999, and so I am familiar with this species. On this recent trip, I was keen to see wild Sumatran orangutans for the first time in their natural habitat.

Prof. Mashhor Mansor of the University of Science, Malaysia (USM), an old friend of mine, kindly introduced me to some talented Indonesian scholars. One of his former students, Dr. Onrizal of North Sumatra University, was my host. I was accompanied by a Kyoto University graduate student, who has been studying Bornean orangutans, in Danum valley for the past three years, and a young Assistant Professor who investigates hormones and behavior in captive zoo-housed orangutans. Together, the five of us toured the northern region of Sumatra.

There are around 6600 orangutans in Sumatra, according to recent estimates. Sumatran orangutans have been studied mainly in the Province of Aceh, in the northern of Sumatra. Field research on Sumatra has been conducted by my good friends Prof. Carel van Schaik, Dr. Sri Suci Utami Atmoko, Dr. Ian Singleton, Dr. Serge Wich, and their colleagues and students.

The Province of Aceh brings to mind the strong earthquake, and subsequent tsunami offshore Northern Sumatra, in 2004. More than 230,000 people are known to have died or are still missing in the wake of this natural disaster. A further challenge was the conflict between the Province of Aceh and the Central Government of Indonesia over natural resources, such as oil. This means, there were security problems related to carrying out fieldwork in Aceh. It was very difficult to get the required permission from the 
government although it seems to be relatively stable at the moment. For these reasons, there have been recent attempts to find new orangutan field sites in the Province of North Sumatra. For example, bordering the south of the Province of Aceh, there is a study site in Sikundur, they collect data since 2013. There are also studies in the Batang Toru forests such as in Tapanuli region.

To see Sumatran orangutans, on our recent trip, we visited Gunung Leuser National Park (GLNP), which straddles the Province of Aceh and the Province of North Sumatra. "Ecotourism" is established in GLNP in Bukit Lawang. With the help of our guides, the National Park Rangers, it was easy to see Sumatran orangutans. They are not really wild orangutans, but ex-rehab and used to tourist visit. April and May is figs season, allowing the orangutans to come together in their huge crowns. So, it helps to see them easily. We saw eight individuals in the forest over two days. The orangutans we saw were adult females, juveniles and infants. We did not see any mature adult males. It is still difficult to see them, because most of them are wild.

Few people realize that orangutans are the largest animal to spend most of their daily life up in the trees; the largest arboreal mammal. I watched with great interest, on one occasion, as a juvenile, about 5 years old, took hold of a bundle of three thin branches, using them as a stick to retrieve a branch on the neighboring tree. Once she had succeeded in moving the tip of the branch towards her, she grabbed it and pulled it gradually closer to her. She appeared to be making sure it was strong enough to bear her weight before moving onto it. Orangutans are very intelligent; they move between trees with great caution.

In the latter half of our journey, we focused on the area of Batang Toru River. We crossed over to the west bank of the river. To do so, we had to take a ferry ride in a boat, hewn from a single massive tree trunk. This seems to be the southern limit of the Sumatran orangutans' range.

Orangutans, just like chimpanzees, make beds to sleep in, up in the trees. We saw many such orangutan sleeping nests in the Batang Toru Forest. We did not see any orangutans, but we were fortunate enough to hear the long call of an adult male. "Hooo, hooo, hooo", the calls continued to be heard across the forest. These calls seem to serve as a keep away signal to other males and an invitation to females.

The Batang Toru Forest is not designated as a National Park. It was owned by the local community so called Production forest, but most of it is moving toward to Protection forest. This is a classic example of a common conflict in Indonesia, where the national government claims the forest lands as state land (as did the colonial government, mostly), whereas local communities claim it as traditional land. This conflict remains to be fully resolved in future. In the forest we visited, people enter it to collect the edible seeds of Parkia spp. trees. We followed trails used by the local people. We encountered the torrential downpours associated with tropical forests. We had to struggle along muddy and slippery paths and there were lots of mosquitos.

The worst thing of all was the leeches. Many leeches climbed up my body. They crawled in at my collar and up my sleeves. I often stopped walking to check my clothes. Red blotches appeared on my white shirt from my own blood. Leeches are able to suck blood from animals without them noticing, because they inject anti-coagulant along with a mild anaesthetic into the bloodstream. This also means that, even once you have removed a leech from your skin fresh blood continues to leak out.

However, the presence of all these leeches meant that there were also a lot of wild animals. Leeches on overhanging leaves gently moved their body back and forth; as though welcoming or inviting us. In Sumatra, as well as Borneo, leeches were the most troublesome creatures we encountered in the course of our fieldwork on orangutans.

The leeches reminded me of a documentary film I saw about Japanese soldiers in the Second World War. During this period, the Japanese Army spread into South East Asia, including Indonesia. Soldiers marching in the jungle must have felt exhausted in the sweltering heat and humid climate, facing waterlogged, muddy trails, mosquitos, and leeches.

The city of Palembang is located in the south of Sumatra. As you may be aware, Indonesia was formerly a Dutch colony. Japan then invaded, driving out the Dutch and occupying Sumatra 1942-1945. Palembang was, at that time, a center of Japanese colonization.

Dr. Onrizal comes from a small village in West Sumatra near Palembang. The story of life under foreign occupation was transmitted from one generation to the next, as an oral history. According to these accounts, Japanese occupation was harsher than the Dutch colonial rule. Why? The Dutch took all the plantation products, such as oil palms and natural rubber. However, the Japanese took such products as well as much rice for the Japanese diet.

This year is the 70th anniversary of the end of the World War Two. However, we must keep in mind that there are many people still living, who survived that difficult time. Dr. Onrizal is 40 years old. He told me that his grandfather was born in 1908 and passed away at the age of 84 . He has memories of his grandfather talking about the trials he faced during the War. Being a true account of his personal experiences, the stories must have been intense and striking. Picture it: the grandfather must have heard stories, of foreign occupation, from his grandfather, in turn. Say that one generation spans about 30 years. The story told by the grandfather of Dr. Onrizal's grandfather, then, allows us to trace 150 years of history; the memories kept vivid in peoples' minds across five generations. 
It is important to see some things in situ. We should see nonhuman primates in their natural habitat through being there in person; walking there in our hiking boots. However, at the same time, it is important to keep in mind what happened there in the past. I think of future possibilities for fieldwork, while reminding myself, always, of the historical context. 